\title{
Toxic acute hepatitis associated to the administration of prostaglandin in a dog
}

\author{
Hepatite tóxica aguda associada à administração de prostaglandina em cão
}

\author{
Mariana Isa Poci Palumbo ${ }^{\mathrm{I}}$ Liliane Celita da Conceição ${ }^{\mathrm{I}}$ Luiz Henrique de Araújo Machado \\ Maria Lúcia Gomes Lourenço ${ }^{I}$ Sabrina Almeida Moreira ${ }^{I}$ Emerson Legatti ${ }^{I}$ \\ Raquel Ribeiro Gutierrez ${ }^{I}$ Maria Denise Lopes ${ }^{I}$
}

\begin{abstract}
Prostaglandin F2 $\alpha$ can be used in dogs to increase ejaculate volume in cases of artificial insemination, semen cryopreservation or reproductive biotechnologies. Side effects after administration of $P G F 2 \alpha$ in dogs as tachycardia, tachypnea, salivation, vomiting, diarrhea and seizures are usually dose- dependent. This paper reports the occurrence of acute toxic hepatitis after the application of $P G F 2 \alpha$ in a dog, and discusses the importance of using this drug with caution in dogs.
\end{abstract}

Key words: prostaglandin $F 2 \alpha$, adverse effects, dogs.

\section{RESUMO}

A prostaglandina $F 2 \alpha$ pode ser usada em caes para aumentar o volume do ejaculado em casos de inseminação artificial, criopreservação seminal ou biotecnologias de reprodução. Os efeitos colaterais após a administração da PGF2a, como taquicardia, salivação, emese, diarréia e convulsões geralmente são relacionadas com a dose utilizada. Esse trabalho objetiva relatar a ocorrência de hepatite tóxica aguda após a administração de PGF2a em um cão, e discutir a importância de se utilizar essa droga com cautela nessa espécie.

Palavras-chave: prostaglandina $F 2 \alpha$, efeitos adversos, caes.

Prostaglandins are a group of biologically active lipids that have aracdonic acid as precursor (BEARDEN \& FUQUAY, 2000). This substance may be considered as a hormone that regulate different phisiological and pharmacological events, such as reproductive and gastrintestinal smooth muscle contractions, penile erection and ejaculation, sperm transport, ovulation, corpus luteum formation, parturition and milk ejection (HAFEZ et al., 2004). Side effects commonly observed with the use of prostaglandins are often dose-dependent and include tachycardia, tachypnea, salivation, vomiting, diarrhea and occasionally seizures (KUSTRITZ \& HESS, 2007).

Hepatic encephalopathy is a complication of severe liver diseases in dogs, specially portosystemic shunts, acute hepatic failure and cirrhosis (DUNAYER \& GWALTNEY, 2006). Several factors have been implicated in the phyosiopathology of hepatic encephalopathy. Most of them are related to the accumulation of substances that are absorbed in the intestines and are not properly metabolized by the liver (DUARTE \& USHIKOSHI, 2005). Encephalopathy is more evident in advanced cirrhosis and in fulminant hepatic failure in patients with acute hepatic injury. The diagnosis of hepatic encephalopathy is made by exclusion and the search for a precipitating factor may be immediately initiated in all cases of encephalopathy (BLEI, 2000).

Besides the effects of encephalopathic toxins themselves, a series of metabolic alterations may

'Faculdade de Medicina Veterinária e Zootecnia (FMVZ), Universidade Estadual Paulista "Júlio de Mesquita Filho" (UNESP), 18618-970, Botucatu, SP, Brasil. E- mail: palumboma11@yahoo.com.br. *Autor para correspondência. 
act in synergy, worsening those effects, as azotemia, hypoxia, electrolyte imbalance, hypoglycemia, alkalosis and hypovolaemia. Patients presenting these abnormalities are predisposed to develop encephalopathy and the correction of those conditions often improves encephalopathic symptoms (DUARTE \& USHIKOSHI, 2005). Measuring plasmatic levels of ammonia is the only practical way to diagnose $\mathrm{HE}$ (ROTHUIZEN, 2009).

Conditions that affect the functions of a metabolic organ such as the liver are considered the most difficult to treat in clinical practice (BRUNETTO et al., 2007). The three goals of encephalopathy treatment are: to decrease the levels of nitrogen compounds at the intestines, to promote extraintestinal elimination of ammonia and to neutralize the abnormalities in central neurotransmission. Many antibiotics have been used in the treatment of hepatic encephalopathy to control bacterial population in the colon (BLEI, 2000).

The aim of the present study is to report the occurrence of acute toxic hepatitis and hepatic encephalopathy clinical signs associated to the administration of prostaglandin in a dog.

A 2-years old, male, rottweiler dog presenting seizures and vocalization was attended by the Small Animal Clinical Service of the FMVZ-UNESP Veterinary Hospital. Approximately five hours before, at the same day, the animal received $0.1 \mathrm{mg} \mathrm{kg}^{-1}$ PGF2 $\alpha$ i.m. (dinoprost tromethamine, Lutalyse ${ }^{\circledR}$, Pfizer, São Paulo) to improve semen collection. After the administration of the drug, the animal was stimulated to move and presented salivation and two episodes of vomiting. Five hours after PGF2 $\alpha$ administration, the animal presented bloody diarrhea, seizures, vocalization and hypoglycemia $\left(40 \mathrm{mg} \mathrm{dL}^{-1}\right)$. Before the administration of prostaglandin, the animal has been examinated and presented normal laboratorial and ultrasonographic exams parameters being considered healthy.

As an attempt to control seizures, $0.5 \mathrm{mg} \mathrm{kg}^{-1}$ diazepam (diazepam, Compaz®, Cristália, Itapira) and $1 \mathrm{~mL} \mathrm{~kg}^{-1} 50 \%$ glucose (Farmavet, São Paulo) were administered intravenously. After the first application of anticonvulsivant, the animal became comatose for approximately 18 hours and several peaks of hypoglycemia were observed. Slow intravenous administration of glucose was made in order to avoid rebound hyperglycemia. Urinary debit was normal. The occurrence of ventricular tachycardia was also observed and treated with bolus of $2 \mathrm{mg} \mathrm{kg}^{-1}$ lidocaine hydrochloride (Hipolabor, Belo Horizonte) in a total of two administrations with a two-hours interval.
Laboratorial exams revealed leukocytosis (31.600 leukocytes $\mathrm{uL}^{-1}$ - normal range 6.000 to 17.000 leukocytes $\mathrm{uL}^{-1}$ ) with predominant segmented neutrophyls. The results of biochemical exams were: alkaline phosphatasis $405 \mathrm{UI} \mathrm{L}^{-1}$ (normal range 20 to $156 \mathrm{UI} \mathrm{L}^{-1}$ ), alanine aminotransferasis (ALT) $1.640 \mathrm{UI} \mathrm{L}^{-1}$ (normal range 21 to $102 \mathrm{UI} \mathrm{L}^{-1}$ ) gamma glutamyl transferasis (GGT) $21 \mathrm{UI} \mathrm{L}^{-1}$ (normal range 1.2 to $6.4 \mathrm{UI}$ $\mathrm{L}^{-1}$ ) and creatinine kinasis (CPK) $1.750 \mathrm{UI} \mathrm{L}^{-1}$ (normal range 20 to $220 \mathrm{UI} \mathrm{L}^{-1}$ ). The values of albumin, globulin, total protein and urinary density were within normal ranges. Urinalysis revealed proteinuria, bilirubinuria, presence of rare erythrocytes per field and mild bilirubin impregnation.

Serum levels of ammonia, which could confirm or discard the suspect of hepatic encephalopathy, could not be verified. Ultrasonographic examination evidenced severe hepatopathy, portal hypertension and splenomegaly. The liver presented regular and definite contours, preserved dimensions, intense hyperechogenicity, specially in right lobes and heterogenic echotexture. Alterations in the biliary tract were not observed inside or outside the liver, nor abdominal effusion.

With those results, it was possible to confirm toxic hepatitis and associated hepatic encephalopathy was suspected. Because of poor prognosis and the emergency of the case, it was decided to proceed assuming that hepatic encephalopathy was present.

Treatment was initiated with manipulated silimarine (50 $\mathrm{mg} \mathrm{kg}^{-1}$, each $12 \mathrm{~h}$, p.o.), lactulose syrup (15mL each 8h, p.o.; Luitpold Sankyo Pharma Brasil, São Paulo), lactulosis enema (3 parts of the product in 7 parts of warm water each $12 \mathrm{~h}$ ), n-acetyl cysteine ( $3 \mathrm{mg}$ $\mathrm{kg}^{-1}$, each 8h, p.o.; Vetnil, Louveira), ursacol (15 $\mathrm{mg} \mathrm{kg}^{-1}$, each 24h, p.o.; Zambon, São Paulo), ceftriaxone (30mg $\mathrm{kg}^{-1}$, each 12h, subcutaneous; Cellofarm, Serra) and metronidazole (10 $\mathrm{mg} \mathrm{kg}^{-1}$, each 12h, i.v.; Sanofi Aventis, São Paulo). Specific diet for patients with liver diseases was also recommended during two months.

Two days after the coma episode, the animal presented cortical blindness, absence of proprioception and depression of consciousness. Another ultrasonographic examination was performed and revealed an extensive hyperechogenic area compatible with cirrhosis, vacuolar hepatopathy or hemorrhage. Twenty days after the first examination, the animal presented mild leukocytosis (18.900 UL), normal serum levels of urea, creatinine, albumin, globulin, total protein, ALT, and GGT, but alkaline phosphatasis was slightly increased (305.1 UI L $\left.{ }^{-1}\right)$. Two months after the beginning of the disease, the animal was asymptomatic and all the complementary exams 
were normal, including blood count, kidney and liver biochemical profiles and urinalysis. At that moment, ultrasonographic examination revealed small hyperechogenic areas, compatible with fibrosis. Three months later, the animal was brought to a complete evaluation and all the physical, laboratorial and ultrasonographical findings were normal.

The inability to maintain glucose homeostasis is presumably caused by glycolitic enzymes system and the loss of hepatocytes with gluconeogenic function, and also because of the commitment of hepatic degradation of insulin (NELSON \& COUTO, 2009a). Patients presenting those abnormalities are predisposed to develop encephalopathy and the correction of those conditions will improve encephalopathy (DUARTE \& USHIKOSHI, 2005). In the present report, the development of seizures may be related to the toxic hepatitis, secondary to hypoglycemia, associated to hypoxia caused by ventricular tachycardia or effect of prostaglandin administration.

Hepatic adverse reaction to a specific drug or environmental toxin should be confirmed by the reexposition of the patient to the suspect substance and further observation of identical consequences (BUNCH, 2000). The fact that the animal has been previously examinated by a veterinary and laboratorial parameters before the administration of PGF $2 \alpha$ suggests that this substance was the cause of acute toxic hepatitis and it was not necessary nor indicated to expose the animal to the risk of another test administration of the drug.

When there is no pre-existing hepatic damage, there are good chances of complete recovery, since the pathogenic aggression has been removed, the patient survives the initial aggression, the permanent loss of functional tissue has been less than $50 \%$ and the liver has maintained its regenerative ability (BUNCH, 2000). In the present report, the animal returned to its normal liver function.

Dose-dependent side effects generally observed with the use of prostaglandins are tachycardia, tachypnea, salivation, vomiting and occasionally seizures (KUSTRITZ \& HESS, 2007). In this report, the animal presented vomiting, bloody diarrhea, salivation and seizures.

Increases of two to three times in ALT serum activity are associated to moderate hepatocytic damage, of five to ten times are observed in more severe cases, and increases higher than ten times suggest intense hepatocytic damage (NELSON \& COUTO, 2009a). In the present case, ALT was increased more than ten times, indicating severe hepatic damage, compatible to acute toxic hepatitis. In view of the complementary exams and clinical signs, the diagnosis of acute toxic hepatitis, probably caused by prostaglandin administration was suggested. The improvement of clinical condition occurred approximately $48 \mathrm{~h}$ after the beginning of hospitalization.

The use of benzodiazepines and corticosteroids should be avoided in the treatment of hepatic encephalopathy (DUARTE \& USHIKOSHI, 2005). In this patient, though, as the cause of the seizures presented by the animal was not known, diazepam was used and this may have induced the coma state in the animal with acute toxic hepatitis.

Splenomegaly is commonly related to hepatic diseases that cause portal hypertension (BUNCH, 2000). The animal in the present case presented both splenomegaly and portal hypertension. If both conditions have not improved with treatment, splenomegaly should be better investigated.

The administration of enema and intravenous fluidtherapy is the basic therapeutic approach. Washing enema with warm water may be useful because it removes colon contents and prevents intestinal absorption of encephalotoxins (NELSON \& COUTO, 2009b).

The acute colateral effect of PGF $2 \alpha$ with involvement of different organs is not reported in the literature, especially with the use of low doses. This patient probably presented severe side effects due to an increased sensitivity to the drug. This report evidences that, although PGF2 $\alpha$ may be indicated when increased semen volumes are required for artificial insemination or associated reproductive technologies, care should be taken due to the possibility of unexpected side effects.

\section{BIOETHICS AND BIOSSECURITY COMMITTEE}

\author{
The protocol of this study in Ethics and \\ Biosecurity Committee is 207/2010.
}

\section{REFERENCES}

BEARDEN, H.J.; FUQUAY, J.W. Neuroendocrine regulators of reproduction. In: _-__-_; _-_-_. Applied animal reproduction. 5.ed. New Jersey: Prentice Hall, 2000. p.3553.

BLEI, A.T. Diagnosis and treatment of hepatic Encephalopathy. Clinical Gastroenterology, v.14, p.959-974, 2000. Disponível em: <http://www.bpgastro.com/article/S15216918(00)90141-0/abstract>. Acesso em: 21 dez. 2010. doi:10.1053/bega.2000.0141.

BRUNETTO, M.A. et al. Manejo nutricional nas doenças hepáticas. Acta Scientiae Veterinariae, v.35, Supl.2, p.233- 
235, 2007. Disponível em: <http://www.ufrgs.br/actavet/35suple-2/05-ANCLIVEPA.pdf>. Acesso em: 21 dez. 2010.

BUNCH, S.E. Distúrbios hepáticos agudos e sistêmicos que acometem o fígado. In: ETTINGER, S.J.; FELDMAN, E.C. Tratado de medicina interna veterinária. 5.ed. Rio de Janeiro: Guanabara Koogan, 2000. p.1398-1417.

DUARTE, R.; USHIKOSHI, W.S. Encefalopatia hepática em cães. Boletim de Medicina Veterinária, v.1, p.57-61, 2005.

DUNAYER, E.K.; GWALTNEY, S.M. Acute hepatic failure and coagulopathy associated with xylitol ingestion in eight dogs. Journal of American Medical Association, v.229, p.1113-7, 2006. Disponível em: <http://www.ncbi.nlm.nih.gov/ pubmed/17014359>. Acesso em: $21 \mathrm{dez} .2010$.

HAFEZ, E.S.S.E. et al. Hormônios, fatores de crescimento e reprodução. In: HAFEZ, E.S.S.E.; HAFEZ, B. Reprodução animal. 7.ed. São Paulo: Manole, 2004. p.33-54.
KUSTRITZ, M.V.R.; HESS, M. Effect of administration of prostaglandin F2alpha or presence of an estrous bitch on characteristics of the canine ejaculate. Theriogenology, v.67, p.255-258, 2007. Disponível em: <http:// www.ncbi.nlm.nih.gov/pubmed/16949658>. Acesso em: $21 \mathrm{dez}$. 2010. doi:10.1016/j.theriogenology.2006.07.009.

NELSON, R.W.; COUTO C.G. Diagnostic tests for the hepatolibiary disease. In: _____________. Small animal internal medicine. 4.ed. Missouri: Mosby Elsevier, 2009a. p.496-520.

NELSON, R.W.; COUTO C.G. Treatment of complications of hepatic disease and failure. In: _____ _____. Small animal internal medicine. 4.ed. Missouri: Mosby Elsevier, 2009b. p.569-578.

ROTHUIZEN, J. Important clinical syndromes associated with liver diseases. Veterinary Clinics of Small Animal, v.39, p.419-437, 2009. 